\title{
An Analysis of Orientalist Discourse in an Alberta Social Studies Text Resource
}

\section{Kimberly Edmondson}

University of Alberta, Canada

speed@ualberta.ca

https://orcid.org/0000-0003-0803-3029

\section{Article Info}

Received: February 18, 2021

Revised: May 30, 2021

Accepted: June 10, 2021

\section{https://doi.org/10.29173/css21}

This is an Open Access article distributed under the terms of the CC BY 4.0

International license.

(https://creativecommons.org/licenses/by/4.0)

\section{ABSTRACT}

The aim of this paper is to explore how the Alberta Social Studies 30-1 textbook, Perspectives on Ideology (Fielding et al., 2009) can contribute to orientalist discourse in its presentation of Islam, especially with respect to terrorism, extremism, and illiberalism - three concepts that appear in the Alberta Social Studies Program of Study. Using a content and discourse analysis, the study found three central findings that contributed to an orientalist framing of Islam: a lack of nuanced discussion of Islam; positioning Islam as a source of terrorism; and a lack of acknowledgement of wrongdoing following injustices perpetrated towards Muslims in Canada. This study concludes by offering ways in which social studies curricular support materials may interrogate to disrupt orientalist discourse, and challenges social studies educators to critically examine the limitations of some of the most common resource materials at their disposal.

\section{KEYWORDS}

curriculum; secondary education; Islamophobia; terrorism; content analysis 


\section{An Analysis of Orientalist Discourse in an Alberta Social Studies Text Resource}

As we approach the twentieth anniversary of the terrorist attacks on the World Trade Center on September 11, 2001 (9/11), high school students in today's classrooms were not alive to experience it firsthand. Instead, their perception of $9 / 11$ is shaped by media portrayals (e.g., film and television), classroom discussions, and textbook representations. This paper explores the ways in which the primary textbook for grade 12 social studies in Alberta, Perspectives on Ideology (Fielding et al., 2009), takes up an orientalist ${ }^{1}$ framing (Said, 1979, 1997) of 9/11, which results in orientalist portrayals of Muslim individuals and communities. This curriculum document was redesigned and implemented in the early 2000 's, a time where the memories of $9 / 11$ were still fresh in many minds, so this paper inquires as to the extent to which commonlyused (and government approved) course materials use orientalism to tether Islam to violent extremists who claim Islam, and how such a framing produces and reproduced ongoing racialization of Muslims.

The textbook, published in 2009, was produced to support a revised social studies curriculum in Alberta (Alberta Education, 2007). The historical context of the development of the textbook is significant to the portrayal of Islam: much of the curriculum and textbook development work occurred just a few years after the terrorist attacks on the World Trade Centre in New York City and the Pentagon in Arlington County, Virginia; and the plane crash in Stonycreek Township, near Shanksville, Pennsylvania on 9/11. Far from coincidental, I argue that the textbook reflects the media portrayals of Islam and the racialization of Muslims in general, as well as West's dominant narrativization of Muslim women and girls (Hoodfar, 1993; Bullock \& Jafri, 2000) through colonial innocence and sexist attitudes that persisted before 9/11 (Said, 1997), and that have since intensified (Sajid, 2005). Furthermore, the textbook uses $9 / 11$ as its primary case study to unpack terrorism and illiberalism, two concepts that are a part of the current Alberta social studies curriculum (Alberta Education, 2007, p.23). Consequently, the textbook reinforces harmful pre-existing stereotypes about Islam and Muslim individuals and communities (Beydoun, 2018; Corbin, 2017), and may influence the ways that students in Social Studies 30-1 might perceive Islam and Muslim individuals and communities. Given the potential for harm, I propose potential pedagogical strategies for classroom teachers to interrogate the discourse, encourage critical thinking, and dismantle stereotypes about Islam and Muslims.

\section{Social Studies Textbooks}

Many social studies educators use textbooks as a main instructional resource in the classroom. Textbooks tend to convey the dominant culture's ideological beliefs, values, assumptions and worldviews (Apple, 2000; Howley, et al., 2013; Peled-Elhanan, 2010). Ideologies can be used to justify the actions of one group towards another group, or to legitimate power, superiority, authority over a group of people (Neumann, 2014). Textbooks can reflect corporate interests that have a hand in shaping educational policy decisions, such as curriculum development (Neumann, 2014), and have agentic qualities that can actualize oppression and inequities through their material representations (Nelson et al., 2021).

In social studies education, textbooks often reflect grand narratives (Schick \& St. Denis, 2005; Stanley, 2006), mythistories (Letourneau, 2006), heroification of prominent political or historical figures (Loewen, 1995), or the villainification of single actors (van Kessel \& Crowley, 2017; van Kessel \& Plots, 2019). These ideological filters influence the portrayal of historical events, such as the Holocaust (e.g. Lindquist, 2009), or the ways that particular groups of people are portrayed within historical narratives (e.g. Brown \& Brown,

\footnotetext{
${ }^{1}$ While Said's (1979) original work capitalized the term “Orientalism," the capitalization of this term today is problematic in that it centers colonialism and whiteness. Borrowing from Hawkman and Shear's (2020) justification for de-capitalizing "white/whiteness," and given the intention of this paper to draw attention to the potential harms that can result from orientalist framings, I have chosen to de-capitalize orientalism and its iterations in this paper, with the exceptions of when it appears at the beginning of a sentence or when present in a title.
} 
2010). Given this ideological filter, many social studies textbooks used in Canada and the United States tend to favor European or Western perspectives and highlight Western - many times male - historical or political figures (Loewen, 1995; Woyshner \& Shocker, 2015). Recently, a broader range of diverse perspectives, including those of Muslim individuals and communities, have been included in textbooks, but are unfortunately, primarily portrayed in light of conflict and violence (Eraqi, 2015) or acts of terrorism (Saleem \& Thomas, 2011), thus reinforcing negative stereotypes and perpetuating Islamophobia (Selod, 2015). Furthermore, textbooks may reflect the media's tendency to overgeneralize Muslims after $9 / 11$ by deliberately or inadvertently presenting monolithic representations of groups with broad ethnic, national, and cultural differences (Rana, 2011); by conflating Arabs and Muslims (Joseph et al., 2008); or by combining racialization and gender identity to reinforce harmful stereotypes (Selod, 2015). These representations, either singularly or combined, produce and reproduce stereotypical "single stories" of Muslim individuals and communities (Saleh, 2017), and may be augmented by students' encounters with other kinds of single stories present in both fiction and non-fiction literature (Marshall \& Sensoy, 2009).

\section{Alberta Social Studies Curriculum and Policy}

In Alberta, social studies textbooks are resources that are custom-designed to specifically reflect the curriculum. Because the textbooks in Alberta are a direct reflection of the curriculum policy document, the textbooks, themselves, are policy artifacts and subject to policy analysis. A critical approach to policy analysis considers the differences between what is presented in policy and what is practiced in reality (Diem et al., 2014), how policies have changed over time, the purpose for changes in policy, and the ways in which policy documents tend to reinforce the dominant culture (Burke, 2004). To help understand educational policies (i.e., relating to curricular documents and textbooks), a critical approach can shed light on how curriculum reflects discourse - the production of knowledge and "truth" (Ball, 1993), and more specifically, as Dwayne Donald has noted, "what knowledge we consider to be of most worth" (UAlberta Sustainability, 2020, 8:05).

The Alberta Social Studies Program of Studies is the curriculum policy document that guides social studies education in all public schools in the province. The current Program of Studies for education in Alberta was implemented between 2005 and 2009, and emphasizes the importance of active citizenship, an appreciation of cultural diversity and pluralism, and a commitment to democratic ideals (Alberta Education, 2008). Following an issues-based approach, the curriculum also prepares students for participating in democratic life by engaging them in critical and historical thinking, considering multiple perspectives, and exploring controversial topics and issues (Alberta Education, 2007; Mundy, 2007). Moreover, this curriculum reflected a post-9/11 lens on foreign policy and international relations, an economic shift toward globalization, and a societal and cultural shift towards the values of tolerance, diversity, pluralism, and multiculturalism, particularly "liberal multiculturalism," which focuses on tolerance and acceptance of differences rather than systemic inequities propagated by differences (Martell \& Stevens, 2021; May \& Sleeter, 2010). At the time of implementing this curriculum, Alberta was at the height of an unprecedented oil boom, resulting in a surge of immigration to Alberta thus, increasingly communal diversity (Mundy, 2007).

The development and rollout of the current curriculum also occurred in the shadow of 9/11, a time when many feared copycat terrorist plots and attacks, especially ones threatened or committed by "foreign actors." Journell (2018) argued that terrorism is an important, challenging, and necessary topic in social studies education because at this point students only know life after 9/11, and that many students' lived experiences may have been shaped by policies, laws, or attitudes that emerged in its aftermath. Perspectives on Ideology, the resource that was analyzed in this paper, addresses $9 / 11$ as a case study, and features critical thinking activities, emphasizes the exploration of multiple perspectives on issues, and engages students in controversial issues. Not surprisingly, as the textbook was published in 2009, some of the issues featured in the textbook are now outdated, or they reflect what Hess (2009) referred to as the "tip," where an issue that was once controversial is now more or less settled.

The senior high curriculum is organized around a series of open-ended essential guiding questions (Related Issues) and categories of general and specific outcomes: Values and Attitudes, Knowledge and Understanding, and Skills and Processes. Ideologies are the central theme of Social Studies 30-1. The course 
engages students in a multi-faceted comparative analysis of democratic liberalism alongside other political and economic ideologies. While the overarching essential question for the course reads, "To what extent should we embrace an ideology?", the question implicitly asks students to what extent they ought to embrace liberalism. In the context of the course, liberalism is defined as an ideology that constitutes those principles related to individualism, personal freedoms, democracy, and civil liberties, as well as equal opportunities to pursue these principles (Fielding et al., 2009).

Salient to this study is Related Issue 3, which asks students "to what extent are the principles of liberalism viable?" (Alberta Education, 2007, p. 23). Related Issue 3 asks students to consider the ways in which the viability of liberalism is maintained amidst these challenges. Three concepts-extremism, terrorism, and illiberalism - are specific "Knowledge and Understanding" outcomes in the Program of Study for this advanced-level Grade 12 course (Alberta Education, 2007) that can perpetuate orientalism. The curriculum lists "terrorism" and "illiberalism" as examples of contemporary issues for which the viability of liberalism may be in question. This part of the course draws on the events and reverberations of 9/11 as case studies to illustrate the tensions between liberal and illiberal actions taken to protect liberal democracy. Knowing that the terrorists' actions during 9/11 were extremist and counter to the principles of liberalism, and given negative stereotypical and bigoted media portrayals of "Muslim terrorists" (Beydoun, 2018; Corbin, 2017), the curriculum positions the textbook to adopt an orientalist (Said, 1979, 1994) framing to engage students in the Related Issue question.

\section{Orientalism}

This study draws on Said's $(1979,1994)$ groundbreaking theoretical framework of orientalism. Orientalism describes the presence of a Western Eurocentric ("occidental") perception of the East or "orient" that has pervaded public and media discourses in the West. Orientalism describes discourse that perpetuates simplistic representations and tropes of the East that reinforce Western cultural hegemony and "institutions, vocabulary, scholarship, imagery, doctrines, even colonial bureaucracies and colonial styles" (Said, 1994, p. 2). The East attempts to establish itself as dominant by creating a stark contrast between itself and the East, reinforcing an "us" versus "them" binary (Watt, 2012). Orientalist representations and tropes of the East reinforce ideas and beliefs that the West upholds safety, security, and familiarity, and that Eastern ideas, beliefs, and people as dangerous, threatening, and strange. Orientalist rhetoric about acts of extremism, terrorism, and illiberalism has contributed to the racialization of Muslim men and women and has propagated acts of violence against Muslim communities (Naseem et al., 2016; Said, 1997). These attitudes are especially apparent in news media (Watt, 2012) and have resulted in an increase in anti-Islamic hate crimes since 9/11 (Byers \& Jones, 2007), such as the Québec City mosque shooting in 2017 (e.g., Zine, 2021), and have informed recent U.S. immigration policies such as the "Muslim ban" that were implemented under the Trump administration in 2017 (e.g., Sisemore \& Iatoui, 2018).

\section{Multiculturalism in Canada and Orientalism}

Canada has a global reputation for being a multicultural nation. Canada's multiculturalism policy is distinct to the country's national identity, and thus, multiculturalism is referred to multiple times within the program of studies. These references are characterized by liberal multiculturalism (May \& Sleeter, 2010) and often position multiculturalism alongside other citizenship education values such as pluralism, respect for diversity, and a desire for social cohesion (Alberta Education, 2007). At face value, Canada's multiculturalism policy and its related values present a vision for a shared, equitable sense of belonging and a unified Canadian national identity. However, this multicultural lens obscures the ways that race and culture intersect with systemic oppression (Ladson-Billings, 2003; Martell \& Stevens, 2021). For example, these policies also reflect Indigenous erasure from the settler-colonial state (Tuck \& Gaztambide-Fernandez, 2013), and renders "Other ethnic groups" as "mere cultural communities peripheral to the now-acknowledged 'two founding races,' the French and the English" (Haque, 2010, p. 81). In other words, Canada's liberal multiculturalism policy discourse reflects orientalism, emphasizing cultural hegemony and Othering while simultaneously deflecting the roots of racial and cultural systemic oppression through the emphasis of multiculturalism as a virtue for 
good citizenship in Canada. Ultimately, because this multicultural lens persists in dominant Canadian culture, it is inevitably reflected in social studies curriculum.

Canada's population is increasingly diverse and multicultural. In 2011, those who identify as Muslim accounted for $3.2 \%$ of the total population in Canada, and visible minorities accounted for $19.1 \%$ of Canada's population (Statistics Canada, 2018). It behooves teachers to consider their approach to teaching their students about multiculturalism. As orientalist attitudes tend to persist via liberal multiculturalism, May and Sleeter (2010) suggests shifting away from viewing multiculturalism through a liberal lens, and instead challenge educators to consider a critical lens to multiculturalism, which "gives priority to the structural analysis of unequal power relationships, analyzing the role of institutional inequities, including, but not necessarily limited to racism" (p. 10). Critical multiculturalism can support other critically reflective engagements such as antiracist work and critical pedagogies (e.g. Gibson, 2020; Gorski \& Dalton, 2020), which can thwart orientalist framings that might appear in classroom resources.

\section{Methodology}

This study draws from both content analysis (e.g., Krippendorff, 2004) and discourse analysis (e.g., Rogers, 2011). Content analysis is concerned with the study of the text itself, separate from the context (Hardy et al., 2004), whereas discourse analysis considers the process of communication (Tesch, 2013) and how the text produces meaning through the social reality, or context, from which it is situated. Gebhard (2017) reminded us that discourse analysis does not provide a summary or narrative, but rather informs how texts function to produce knowledge. Foucault (1982) emphasized that knowledge production is driven by power relations. This study engages both kinds of analysis to examine not only the extent to which Islam is included in the textbook discussion, but also who determined the inclusion or exclusion of Islam, how Islam is discussed within the social and temporal reality of when the textbook was produced, and how Islam is featured in the context of the textbook's topics and themes.

I collected data by identifying key words to guide my search for where Islam is mentioned in the textbook. To guide this search, I used the textbook's index, and manually scanned each individual page for the following terms: Islam, Islamism, Islamic Law, or Muslim. I marked the physical pages of the text with sticky notes in order to record specific details about the location of the term in the textbook (e.g., page number, chapter, heading, etc.). For each place where I identified a mention of one or more of the above terms, I recorded the page number, the chapter, and the heading under which the term was located. I recorded all of my findings in a spreadsheet. In total, Islam or its related terms was mentioned a total of 22 times in the text, with 15 of the 22 located within Related Issue 3: "To what extent are the principles of liberalism viable?" Given the essential question in Related Issue 3, which asks students to consider the extent to which liberalism is viable, it is evident that within the textbook, students are repeatedly asked to consider this question alongside Islam.

\section{Findings}

Three significant findings reflect an orientalist framing of Islam as a threat to the viability liberalism emerged from the discourse on Islam in the textbook, which are: a lack of nuanced discussion of Islam; Islam named in relation to terrorism, terrorist groups or extremism; and a lack of admission of wrongdoing on the part of liberal governments towards Muslim individuals accused of terrorism. Overall, these findings suggest that the textbook resource contributes to a discourse that perpetuates the racialization of Muslim individuals and communities.

\section{Little Nuance to Discussions of Islam}

There is little evidence of a nuanced discussion of Islam as a religion throughout the textbook, especially in comparison to the textbook's discussion of Christianity. Though the course focuses on political and economic ideologies and is not a religion course, when compared to Christianity, little time is spent describing Islam as a religion at all. In contrast, the textbook attends to some of the nuances within the Christian faith, such as mentioning a brief history of Christianity (p. 67) and describing some differences between 
Protestantism and Catholicism (pp. 67-68). Specifically, the textbook addresses the "Christian Right" as a distinct group of Christians whose religious beliefs strongly inform their political views (p. 290).

Overall, the textbook lacks a nuanced discussion of Islam. For instance, the textbook does not distinguish between Islam as a faith and those who use Islam to advance political ideologies, and makes little distinction between Islam as a faith and the mis/understandings of Islam as claimed by violent extremists (Lipka, 2017). In fact, the textbook explicitly connects political ideology with so-called Islamism: "Islamism uses the tenets of Islam and Islamic law as the basis for a political system" (p. 36), but does not explain in what ways this differs from the faith of Islam. This narrow framing, reinforced by simplistic media portrayals could mislead students with little knowledge of Islam to conflate the two. Additionally, the brief discussion of "Christian Democracy" a few lines above, implies a contrast in values between it and Islamism. The juxtaposition of these two binaries, Christianity/Islam, and Democracy/Islamic Law perpetuate an orientalist framing of "us" versus "them," and hegemonic (mis)perception that the West is free and the East is oppressive.

One notable exception to the overall lack of nuance occurs when the textbook attempts to address some of the reasons why some Muslim women choose to wear the veil. Supporting the orientalist imagination of Muslim women, Bullock and Jafri (2000) explain that the idea of the "Canadian woman" has been constructed in contrast to the idea of "third-world woman," and the hijab can signify "Otherness" (p. 35). Furthermore, the West often fixates on the hijab as a symbol of women's oppression, suggesting that (especially veiled) MuslimCanadian women embody "un-Canadian" values (Bullock \& Jafri, 2000, p. 37), and are "often storied by the media and in literature as any combination of the following: poor, uncivilized, oppressed, meek, exotic, suspicious, less-than, and primitive" (Saleh, 2017, p. 38). The textbook does not interrogate the existing public discourse that wearing the hijab defies "Canadian values," however, in one instance it makes a brief reference to possible political or social reasons why Muslim women and girls wear the veil: “...the wearing of hijabs, the headscarves worn by some Muslim women as an expression of modesty, as a symbol of faith, and sometimes as a sign of their commitment to Islamic movements or groups, whether social or political [emphasis added]" (p. 390). In reality, Muslim women and girls practice hijab for a multiplicity of reasons (Saleh, 2017, p. 39) including but not limited to, declaring one's faith in a visible way, demonstrating modesty, or being perceived as respectable (Ruby, 2005). Despite this, the textbooks make explicit connections between the faith of Islam and political movements claiming Islam which may perpetuate misunderstandings. This suggestion is reinforced by the placement of a photograph of a veiled woman juxtaposed with the bolded keyword, "illiberal" in the preceding paragraph (Fielding et al., 2009, p. 390). The combination of the photograph and the bolded text draw the reader's eye, perhaps reinforcing the orientalist framing perpetuated in media and public discourse that Islam opposes and threatens liberalism (p. 390).

\section{Islam as Terrorism}

The textbook augments existing discourse about terrorism and Islam by providing scant examples of terrorist actions that are connected to any other groups other than Muslims (with the exception of the October Crisis that took place in Quebec in 1970), despite numerous references to the concept of terrorism. It discusses this connection both generally, as in describing "pro-Islamic forces in the Middle East" (Fielding et al., p. 363), specifically naming Hezbollah as an "Islamic political and paramilitary organization" (p. 455) as well as alQaeda (pp. 320-321; 413) and the Taliban (pp. 322 -323) as terrorist organizations that have claimed Islam. In addition to being associated with terrorism, the Taliban is also named as committing human rights abuses against women, which violates liberal principles (pp. 322-323); and Al-Qaeda is mentioned several times and connected with other curriculum keywords like extremism (p. 413) and the "war on terror" (pp. 320-321). Taken together, the intertwined portrayal of these terrorist organizations alongside references to Islam reinforce mis/understandings about violent extremists who have claimed Islam, and reflects the orientalist framing that the primary threat of terrorism in the West exists as a result of foreign actors from the East.

The absence of other relevant examples of terrorism (e.g., the Oklahoma City Bombing) perpetuates existing Western post-9/11 discourse that associates Islam with radical Islamic terrorist groups as threatening to liberalism, and reinforces the orientalist "us' versus "them" binary. One potential consequence of an absence of discussion of other examples of terrorism besides those committed by violent extremists who claim to be 
Muslim is that students may perceive terrorism as acts of violence committed solely by "foreign actors," and negate or downplay the harms that result from violent acts of domestic terrorism, such as the sieging of the U.S. Capitol Building on January 6, 2021 (e.g., Freiman, 2021). In 2020, more than 67\% of terrorist plots and attacks were committed by domestic terrorist groups promoting far-right extremism (Jones et al., 2020). Bearing in mind that the textbook was published in 2009, it would behoove teachers to have students consider the ways in which acts of terrorism committed by other groups call into question the viability of liberalism, especially in light of recent events.

\section{Lack of Acknowledgment of Canadian Wrongdoing}

The textbook downplays the Canadian government's actions regarding the violation of a Muslim man's individual rights as a result of the Canadian government enforcing post-9/11 national security measures designed to prevent terrorism. Maher Arar, a Syrian-born Muslim Canadian citizen was subjected to racial profiling, torture, and detainment as a means for the Canadian government to glean intelligence about potential terrorist plots against Canada and the U.S. Arar was returning home from a vacation when he was arrested in New York on charges of terrorism. Under the heading, "Complexities of Liberalism in Practice," the text discusses Arar's case, summarizing that, "Three years later a Canadian commission found no evidence that Arar had any terrorist connection" (Fielding et al., 2009, p. 368). Despite evidence of the Canadian government engaging in ethnic and Islamophobic profiling to raise allegations of Arar as a terrorist because he is a Muslim, the textbook does not name that Arar was profiled because he is Muslim. Additionally, the term "complexities" in the heading, as opposed to words like "violations" for example, functions to soften the impact of the violence and violation of rights perpetrated by the Canadian government towards Arar. Describing this case study as an example of liberalism's "complexity" downplays and even excuses Canada's actions, implying that defending Canada from terrorism sometimes is a moral dilemma with "complex" collateral damage, and Arar was an unfortunate victim of such. Arar's case is mentioned again under the heading "Canada's No-Fly List." The reference to a no-fly list implies not only a security threat, but foreign terrorism similar to 9/11. As Arar is mentioned here again, the textbook reinforces the association between Arar and terrorism, even though Arar was found innocent (CBC News, 2007; Shane, 2005).

Furthermore, the textbook uses the passive voice to discuss Arar's experience. Raibmon (2018) explains that the passive voice is often used in textbooks, and "in nearly every instance, it obfuscates rather than clarifies" ("Who did what to whom?" section). In this case, the passive voice is used to obfuscate the role of the U.S. and Canadian governments in Arar's torture. While the textbook states that, "Arar was questioned, held, and eventually deported to Syria" (Fielding, et al., 2009, p. 403), it does not state that it was the U.S. authorities who deported Arar. When the textbook states, "he was tortured and held in Syria until October 2003" (p. 403), it fails to mention that Arar was held in Syria for ten months because Canadian authorities perceived him to be a threat, despite a lack of evidence, and denied him entry back to Canada (p. 403). Failing to mention that Arar was innocent, as well as the textbook's passive voice, reflect the ways that orientalism frames the West as not only superior, but presents the interests of the West as virtuous (Said, 1994), and justifies the actions the actions of the Canadian and U.S. governments. As a result, the passive voice reinforces public and media discourse that associates Muslims with terror organizations, while also protecting Canada's supposed benevolent and democratic values.

\section{Discussion}

Despite fervent efforts on the part of many individual teachers to be critically reflective as they engage in anti-racist and other forms of critical pedagogy in their classrooms (e.g., Gibson, 2020; Gorski \& Dalton, 2020), Othering of Muslims persists in Alberta schools (e.g. Abdul-Jabbar, 2019, Amjad, 2018). Additionally, this study confirms that high school students are exposed in (not so) subtle ways to discourses from learning materials and resources that normalize the association between Islam and violent extremists who claim Islam. Given that humans tend to uncritically accept information, stories, and perspectives that align with our worldviews (Williams et a., 2012), and be defensive when presented with other worldviews (van Kessel et al., 2020), educators need to be aware that some high school students may perceive examples of terrorism and extremism as worldview-threatening. In an attempt to defend themselves from worldview threat, humans may 
exhibit defensive behaviours, such as derogation or scapegoating of an "Other" to protect their worldview (van Kessel et al., 2021). Because orientalism inherently Others those associated with the East, discourse that connects Islam with terrorism may be perceived as worldview-confirming to some, and may go unchallenged. Furthermore, because media and public discourse in Canada continues to affirm simplistic representations of Islam (Haque, 2010; Watt, 2012), non-Muslim students who read worldview-confirming information about Islam may not critically question or criticize those representations without prompting.

To this end, teachers must take an active role in interrogating these simplistic yet harmful representations with their students. However, despite its flaws, there are some reasons why some teachers may continue to use the textbook resource. From an equity standpoint, textbooks provide students with convenient access to resources for learning. Because Perspectives on Ideology is a government-approved, custom resource for the entire Social 30-1 course, the textbook is also an adequate resource for students to explore other themes related to the course. Additionally, teachers who are perhaps new to teaching this course may rely more heavily on the text resource as it aligns with the Program of Study. While teachers may choose not to abandon the textbook for many reasons, teachers may overlook the ways this textbook falls short of accurately representing the multiplicities and complexities of Muslim individuals and communities. Regardless of intention, the overgeneralized representations of the faith of Islam, alongside the narrow portrayals of Muslim individuals and communities that exist in the textbook, serve to perpetuate harmful stereotypes. Therefore, it is imperative that teachers actively pursue opportunities to engage students in questioning and critiquing the simplistic representations of Islam in the text in the classroom context. This study offers evidence for how seemingly benign materials, such as textbooks, may indeed lack the cultural competence necessary for socially just teaching and learning.

The textbook resource in this study provides only limited and narrow representations of Islam and Muslims, which have the potential to perpetuate the Othering of Muslim individuals and communities. This fraught portrayal may open up the opportunity for teachers to acknowledge the ways in which "single stories" of Muslims (Adichie, 2009; Saleh, 2017) exist in the textbook, and elsewhere, and contribute to harmful stereotypes. To compliment this exploration, teachers might also consider using counter-stories (Madden, 2019) to supplement the textbook resources (i.e., portrayals of Islam or Muslims that defy these representations). Additionally, teachers might have students consider case studies disrupt the idea that terrorism and extremism are caused by foreign actors, and add to the conversation the resurgence of domestic terrorism, particularly the rise in far-right extremism in recent years (Jones et al., 2020). For example, students could explore the ways in which the viability of liberalism was threatened in the U.S. during the Oklahoma City Bombing (e.g. Cooper, 2020), continues to be questioned by the siege on the U.S. Capitol in 2021, and remains precarious at the intersection of far-right conspiracy theories and their infringement on civil liberties, such as the outcomes of democratic elections (e.g. Levine, 2021). Teachers might also engage students in unpacking the ways in which the freedom to practice the Islamic faith has been threatened by terrorism in liberal societies, such as the Quebec mosque shooting (e.g. Kassam \& Lartey, 2017), and the terrorist attacks on two mosques in Christchurch, New Zealand (e.g. CBC News, 2019). Using these kinds of case studies, students might interrogate the discourse around the media portrayal of this act of domestic terrorism, including how the media shied away from referring to Alexandre Bissonnette as a terrorist, instead referring to him as the "mosque shooter" (The Canadian Press, 2020).

\section{Conclusion}

This study highlights the ways in which the presence of orientalist framings of Islam in the Social 301 textbook are both explicit and insidious, which can augment mis/understandings between Islam as a faith and violent extremists who have co-opted Islam. As part of a larger body of research that critically examines the content of social studies textbooks, this paper acknowledges that despite shifting values in Canadian culture and in curriculum that embrace diversity and multiculturalism, orientalist framings persist in classroom resources and materials, which may produce or re-produce racist attitudes about Muslim individuals and communities. As a result, I hope that this study will invite both teachers and students to engage in critical thinking and dialogue about how the selection of resources can shape our understandings and frame our 
discussions of race and racialized groups. Overall, the aim of this study was to challenge social studies educators to critically examine the limitations of some of the most common resource materials at their disposal, and actively challenge students to think critically about how authoritative texts like textbooks might perpetuate harmful discourse and stereotypes.

\section{Acknowledgement}

The author wishes to thank Dr. Alexandre Da Costa for his gracious feedback and encouragement to publish this article.

\section{References}

Abdul-Jabbar, W. K. (2019, May 7). Arab Muslim Canadian high school students call for globalized curriculum to change stereotypes. The Conversation. https://theconversation.com/arab-muslimcanadian-high-school-students-call-for-globalized-curriculum-to-change-stereotypes-112643

Adichie, C. N. (2009). The danger of a single story [Video]. TED.

https://www.ted.com/talks/chimamanda_ngozi_adichie_the_danger_of_a_single_story/transcript?lan guage $=\mathrm{en}$

Alberta Education. (2007). Program rationale and philosophy for social studies: Kindergarten to Grade 12; Social Studies 10-12 Program of Studies. https://education.alberta.ca/media/3386090/program-ofstudy-grade-12.pdf

Alberta Education. (2008). Guide to education. https://open.alberta.ca/dataset/d119dba4-36cd-4e41-927bb436fb2e75b1/resource/8d73a3d6-31c3-4569-8969-c09e0cfc7428/download/guide-to-ed-20082009.pdf

Apple, M. W. (2000). Official knowledge: Democratic education in a conservative age ( $2^{\text {nd }}$ ed.). Routledge.

Ball, S. J. (1993). What is policy? Texts, trajectories and toolboxes. The Australian Journal of Education Studies, 13(2), 10-17. https://doi.org/10.1080/0159630930130203

Beydoun, K. A. (2018). American Islamophobia: Understanding the roots and rise of fear. University of California Press.

Brown, A. L., \& Brown, K. D. (2010). Strange fruit indeed: Interrogating contemporary textbook representations of racial violence toward African Americans. Teachers College Record, 112(1), 3167. http://www.tcrecord.org/Content.asp?ContentId=15592

Burke, P. (2004). What is cultural history? Polity Press.

Bullock, K. H., \& Jafri, G. J. (2000). Media (mis)representations: Muslim women in the Canadian nation. Canadian Woman Studies, 20(2), 35-40.

Byers, B. D. \& Jones, J. (2007). The impact of the terrorist attacks of 9/11 on anti-Islamic hate crime. Journal of Ethnicity in Crime Justice, 5(1), 43-56.

Canadian Press. (2020, November 27). Quebec City mosque shooter's sentence reduced by 15 years. CTV News. https://montreal.ctvnews.ca/quebec-city-mosque-shooter-s-sentence-reduced-by-15-years$\underline{1.5205695}$

CBC News. (2007, January 25). Ottawa reaches $\$ 10 M$ settlement with Arar. https://www.cbc.ca/news/canada/ottawa-reaches-10m-settlement-with-arar-1.682875 
CBC News. (2019, March 15). New Zealand mosque shootings: What we know about the alleged gunman. https://www.cbc.ca/news/world/nz-mosque-shootings-what-we-know-1.5057734

Cooper, K. (2020, April 18). Oklahoma City bombing: The day domestic terror shook America. BBC News. https://www.bbc.com/news/world-us-canada-51735115

Corbin, C. M. (2017). Terrorists are always Muslim but never white: At the intersection of critical race theory and propaganda. Fordham Law Review, 86(2), 455-485.

https://ir.lawnet.fordham.edu/cgi/viewcontent.cgi?article=5437\&context=flr

Diem, S., Young, M. D., Welton, A. D., Mansfield, K. C., \& Lee, P. L. (2014). The intellectual landscape of critical policy analysis. International Journal of Qualitative Studies in Education, 27(9), 1068-1090. https://doi.org/10.1080/09518398.2014.916007

Eraqi, M. M. (2015). Inclusion of Arab-Americans and Muslim-Americans within secondary U.S. history textbooks. Journal of International Social Studies, 5(1), 64-80.

Fielding, J., Christison, M., Harding, C., Meston, J., \& Smith, T. (2009). Perspectives on ideology. Oxford University Press.

Foucault, M. (1982). The subject and power. Critical Inquiry, 8(4), 777-795. https://www.jstor.org/stable/1343197

Freiman, J. (2021, January 7). 4 dead after Trump supporters storm U.S. Capitol. CBS News. https://www.cbsnews.com/news/trump-supporters-us-capitol-4-dead/

Gebhard, A. (2017). Reconciliation or racialization? Contemporary discourses about residential schools in the Canadian prairies. Canadian Journal of Education, 40(1), 1-30. https://www.jstor.org/stable/90002340

Gibson, M. (2020). From deliberation to counter-narration: Toward a critical pedagogy for democratic citizenship. Theory \& Research in Social Education, 1-24. https://doi.org/10.1080/00933104.2020.1747034

Gorski, P. C., \& Dalton, K. (2020). Striving for critical reflection in multicultural and social justice teacher education: Introducing a typology of reflection approaches. Journal of Teacher Education, 71(3), 357-368. https://doi.org/10.1177/0022487119883545

Haque, E. (2010). Homegrown, Muslim and other: Tolerance, secularism and the limits of multiculturalism. Social Identities, 16(1), 79-101. https://doi.org/10.1080/13504630903465902

Hardy, C., Harley, B., \& Phillips, N. (2004). Discourse analysis and content analysis: Two solitudes? Qualitative Methods, 2(1), 19-22. https://core.ac.uk/download/pdf/144874836.pdf

Hawkman, A.M., \& Shear, S.B. (2020). Taking responsibility, doing the work: An introduction to Marking the 'Invisible.' In A.M. Hawkman \& S.B. Shear (Eds.), Marking the "invisible”: Articulating whiteness in social studies education. Information Age.

Hess, D.E. (2009). Controversy in the classroom: The democratic power of discussion. Routledge.

Howley, M., Howley, A., \& Eppley, K. (2013). How agricultural science trumps rural community in the discourse of U.S. history textbooks. Theory \& Research in Social Education, 41(2), 187-213. http://dx.doi.org/10.1080/00933104.2013.778715 
Hoodfar, H. (1993). The veil in their minds and on our heads: The persistence of colonial images of Muslim women. Resources for Feminist Research, 22(3/4), 5-18. https://doi.org/10.1007/978-1-137-04830$1 \_22$

Jones, S. G., Doxsee, C., Hwang, G., Suber, J., \& Harrington, N. (2020, October 22). The war comes home: The evolution of domestiv terrorism in the United States. Center for Strategic International Studies. https://www.csis.org/analysis/war-comes-home-evolution-domestic-terrorism-united-states

Joseph, S., D’Harlingue, B., \& Wong, K. H. (2008). Arab Americans and Muslim Americans in the New York Times, before and after 9/11. In A. Jamal \& N. Naber (Eds.), Race and Arab Americans before and after 9/11: From invisible citizens to visible subjects. Syracuse University Press.

Journell, W. (2018). Terrorism. In D. Krutka, A. McMahon Whitlock, \& M. Helmsing (Eds.), Keywords in the Social Studies (pp. 217-229). Peter Lang.

Kassam, A., \& Lartey, J. (2017, January 30). Quebec City mosque shooting: Six dead as Trudeau condemns 'terrorist attack.' The Guardian. https://www.theguardian.com/world/2017/jan/30/quebec-mosqueshooting-canada-deaths

Krippendorff, K. (2004). Content analysis. An introduction to its methodology (2nd ed.). Sage.

Ladson-Billings, G. (2003). Lies my teacher still tells: Developing a critical race perspective toward the social studies. In G. Ladson-Billings (Ed.), Critical race theory perspectives on social studies: The profession, policies, and curriculum (pp. 1-11). Information Age.

Létourneau, J. (2006). Remembering our past: An examination of the historical memory of young Québécois. In R. W. Sandwell (Ed.), To the past: History education, public memory, and citizenship in Canada, 70-87.

Levine, S. (2021, May 14). Cyber Ninjas, UV lights and far-right funding: Inside the strange Arizona 2020 election 'audit.' The Guardian. https://www.theguardian.com/us-news/2021/may/14/arizonaelection-audit-recount-ballots-maricopa-county

Lindquist, D. H. 2009. The coverage of the Holocaust in high school History textbooks. Social Education, 73(6), 298-304.

Lipka, M. (2017, August 9). Muslims and Islam: Key findings in the U.S. and around the world. Pew Research Center. https://www.pewresearch.org/fact-tank/2017/08/09/muslims-and-islam-keyfindings-in-the-u-s-and-around-the-world/

Loewen, J. W. 1995. Lies my teacher told me: Everything your American history textbook got wrong. The New Press.

Madden, B. (2019, March 11). Indigenous counter-stories in truth and reconciliation education: Moving beyond the single story of victimhood. EdCan Network. https://www.edcan.ca/articles/trc-education/

Martell, C. C., \& Stevens, K. M. (2021). Teaching history for justice. Teachers College Press.

May, S., \& Sleeter, C. E. (Eds.). (2010). Critical multiculturalism: Theory \& praxis. Routledge.

Naseem, A., Arshad-Ayaz, A., Duckworth, C. L., \& Savard, M. (2016). Teaching about terror: 9/11: Policy, pedagogy, and curricula. Contemporary Issues in Education, 11(1), 1-5. https://doaj.org/article/a9e2d93d3df647408ff6289ced55ac79 
Nelson, P. M., Segall, A., \& Durham, B. S. (2021). Between aspiration and reality: New materialism and social studies education. Theory \& Research in Social Education. Advance online publication. https://doi.org/10.1080/00933104.2021.1912679

Neumann, R. (2014). An analysis of the treatment of corporate influence on government by United States history and American government high school textbooks. Social Studies, 105(2), 57-68. https://doi.org/10.1080/00377996.2013.820163

Marino, M. P. 2011. High school World History textbooks: An analysis of content focus and chronological approaches. The History Teacher, 44(3), 421-446.

Marshall, E., \& Sensoy, Ö. (2009). “Save the Muslim girl!” Rethinking Schools Online, 24(2). https://rethinkingschools.org/articles/save-the-muslim-girl/

Moore, J. R. (2012). A challenge for social studies educators: Teaching about Islam, "Jihad," and "Shari'ah" law. Social Studies, 103(5), 179-187. https://doi.org/10.1080/00377996/2011.601357

Mundy, K. (2007). Charting global education in Canada's elementary schools: Provincial, district, and school-level perspectives. Ontario Institute for Studies in Education. https://www.unicef.ca/sites/default/files/imce_uploads/UTILITY\%20NAV/TEACHERS/DOCS/GC/ ChartingGlobalEducationinElementarySchools.pdf

Peled-Elhanan, N. 2010. Legitimation of massacres in Israeli school history books. Discourse \& Society, 21(4), 377-404. https://doi.org/10.1177/0957926510366195

Raibmon, P. (2018, October 24). Provincializing Europe in Canadian history; Or, how to talk about relations between Indigenous peoples and European. Active History. http://activehistory.ca/2018/10/provincializing-europe/

Rana, J. (2011). Terrifying Muslims: Race and labor in the South Asian diaspora. Duke University Press.

Rogers, R. (Ed.). (2011). An introduction to critical discourse analysis in education. Routledge.

Ruby, T. F. (2006). Listening to the voices of hijab. Women's Studies International Forum, 29(1), 54-66. https://doi.org/10.1016/j.wsif.2005.10.006

Said, E. W. (1979). Orientalism. Vintage.

Said, E. W. (1994). Orientalism (25th anniversary edition). Vintage.

Said, E. W. (1997). Covering Islam: How the media and the experts determine how we see the rest of the world. Vintage.

Sajid, A. (2005). Islamophobia: A new word for an old fear. Palestine-Israel Journal of Politics, Economics, and Culture, 20(2-3), 31.

Saleem, M. M., \& Thomas, M. K. (2011). The reporting of the September $11^{\text {th }}$ terrorist attacks in American social studies textbooks: A Muslim perspective. High School Journal, 95(1), 15-33. https://doi.org/10.1353/hsj.2011.0015

Saleh, M. (2017). Stories we live by, with, and in: A narrative inquiry into the experiences of Canadian Muslim girls and their mothers [Unpublished doctoral dissertation]. University of Alberta.

Schick, C., \& St. Denis, V. (2005). Troubling national discourses in anti-racist curricular planning. Canadian Journal of Education, 28(3), 295-317. http://www.csse.ca/CJE/Articles/CJE28-3.htm

Selod, S. (2015). Citizenship denied: The racialization of Muslim American men and women post 9/11. Critical Sociology, 4(1), 77-95. https://doi.org/10.1177/08969205 
Shane, S. (2005, May 29). The costs of outsourcing interrogation: A Canadian Muslim's long ordeal in Syria. The New York Times. https://www.nytimes.com/2005/05/29/world/americas/the-costs-ofoutsourcing-interrogation-a-canadian-muslims.html

Sisemore, B., \& Iatoui, R. (2018, January 29). Trump's travel ban is just one of many U.S. policies that legalize discrimination against Muslims. The Conversation. https://theconversation.com/trumpstravel-ban-is-just-one-of-many-us-policies-that-legalize-discrimination-against-muslims-89334

Stanley, T. (2006). Whose public? Whose memory? Racisms, grand narratives, and Canadian history. In R. W. Sandwell (Ed.), To the past: History education, public memory, and citizenship in Canada, (pp. 32-49). University of Toronto Press.

Statistics Canada (2018, July 25). Immigration and ethnocultural diversity in Canada. https://www12.statcan.gc.ca/nhs-enm/2011/as-sa/99-010-x/99-010-x2011001-eng.cfm

Tesch, R. (2013). Qualitative research: Analysis types and software. Routledge.

Tuck, E., \& Gaztambide-Fernández, R. A. (2013). Curriculum, replacement, and settler futurity. Journal of Curriculum Theorizing, 29(1). https://journal.jctonline.org/index.php/jct/article/viewFile/411/pdf

UAlberta Sustainability. (2020, January 28). Dwayne Donald- homo economicus and forgetful curriculum: Remembering other ways to be a human being [Video]. YouTube. https://www.youtube.com/watch?v=VM1J3evcEyQ

van Kessel, C., \& Crowley, R. M. (2017). Villainification and evil in social studies education. Theory \& Research in Social Education, 45(4), 427-455. https://doi.org/10.1080/00933104.2017.1285734

van Kessel, C., den Heyer, K., \& Schimel, J. (2020). Terror management theory and the educational situation. Journal of Curriculum Studies, 52(3), 428-442. https://doi.org/10.1080/00220272.2019.1659416

van Kessel, C., Jacobs, N., Catena, F., \& Edmondson, K. (2021). Responding to worldview threats in the classroom: An exploratory study of pre-service teachers [Manuscript submitted for publication]. Department of Secondary Education, University of Alberta.

van Kessel, C., \& Plots, R. (2019). A textbook study in villainification: The need to renovate our depictions of villains. One World in Dialogue, 5(1), 21-31.

https://ssc.teachers.ab.ca/publications/Pages/OneWorldInDialogue.aspx

Watt, D. (2012). The urgency of visual media literacy in our post-9/11 world: Reading images of Muslim women in the print new media. Journal of Media Literacy Education, 4(1), 32-43. https://digitalcommons.uri.edu/jmle/vol4/iss1/4/

Woyshner, C., \& Schocker, J. B. (2015). Cultural parallax and content analysis: Images of Black women in high school history textbooks. Theory \& Research in Social Education, 43(4), 441-468. https://doi.org/10.1080/00933104.2015.1099487

Zine, J. (2021, January 28). Remembering the Québec City mosque attack: Islamophobia and Canada's national amnesia. The Conversation. https://theconversation.com/remembering-the-quebec-citymosque-attack-islamophobia-and-canadas-national-amnesia-152799 